\title{
Variations in The Vascular Supply of Pancreas and Transverse Colon: A Case Report
}

\author{
Variaciones en el Suministro Vascular de Páncreas y Colon Transverso: Reporte de un Caso
}

\author{
Silva Júnior, L. M.*; Alexandre, M.*; Gonçalves, L.**; Silva, F. S.** \& Caetano, A. G.**
}

SILVA JÚNIOR, L. M.; ALEXANDRE, M.; GONÇALVES, L.; SILVA, F. S. \& CAETANO, A. G. Variations in the vascular supply of pancreas and transverse colon: a case report. Int. J. Morphol., 32(1):190-193, 2014.

SUMMARY: During anatomical dissection of the abdominal cavity of an adult male corpse, a changing pattern of vascular supply of pancreas and of the transverse colon was observed. The inferior pancreatic artery and the middle colic artery arose from a common trunk of the superior mesenteric artery. Moreover, the lienal artery did not direct a dorsal branch to the neck of the pancreas, but rather sent two greater pancreatic arteries (proximal and distal) to the body of the gland and one caudal artery to the terminal portion of the pancreas. We also observed a large communicating branch between the proximal portion of the middle colic artery and the ascending branch of the left colic artery, previously described as artery of Moskowitz. Based on these data, clinical and surgical implications of these variations were highlighted.

KEY WORDS: Anatomic variation; Blood supply; Pancreas; Large intestine.

\section{INTRODUCTION}

The pancreas is an exocrine and endocrine gland whose vascular supply consists of branches from the celiac trunk and from the superior mesenteric artery (SMA). Each part of the gland is supplied by specific branches which, after entering the parenchyma, anastomose to form a dense vascular network necessary for pancreatic function (Bertelli et al., 1995; Gardner et al., 1975).

The colon, on the other hand, is supplied by branches from the SMA and inferior mesenteric arteries (IMA), with the IMA distributed from the left half of transverse colon. The branches of these arteries form a long marginal arcade extending variably along the colon, and which may extend from the cecum to the sigmoid colon (Geboes et al., 2001; Shatari et al., 2003).

Although there is an anatomical supply pattern for the different organs and tissues, anatomical variations of the vascular system are very common, so it is essential for anatomists and surgeons to be aware of that.

In this context, we reported a varying pattern of pancreas and transverse colon vascular supply, which was not found in the literature.

\section{CASE REPORT}

During the anatomical dissection of the abdominal cavity of a 40 to 45 -year-old male cadaver, a varying pattern of pancreas and transverse colon vascular supply was observed. Macroscopically, the pancreas and transverse colon showed eutrophic conditions, with preserved sizes, shapes and relationships.

We observed the presence of an arterial trunk of 0.6 $\mathrm{cm}$ in both length and diameter, which emerged from the SMA (3 cm after its origin on Aorta) and bifurcated into the middle colic artery (MCA) and the inferior pancreatic artery (IPA). The IPA, with $7.5 \mathrm{~cm}$ in total length and $0.4 \mathrm{~cm}$ in diameter, followed an ascending path towards the inferior surface of the body of the pancreas. This artery directed two branches to the neck of the pancreas (anterior and posterior) and it continued to the left with extra-pancreatic extension of $5.8 \mathrm{~cm}$ before penetrating the inferior border of the body of the pancreas (Fig. 1).

A varying pattern of the branches of the lienal artery (LA) was also observed in the vascular supply of pancreas. The dorsal pancreatic artery (DPA), which is usually the first branch of the LA, was absent, whereas two greater pancreatic arteries (proximal and distal) were observed towards the body

\footnotetext{
* Medical Student, Triangulo Mineiro Federal University, Uberaba, Brazil.

** Institute of Biological and Natural Sciences, Division of Human Anatomy, Triangulo Mineiro Federal University, Uberaba, Brazil.
} 
of the pancreas. The vascular supply for the caudal portion of pancreas was made by the caudal pancreatic artery (CPA) (Fig. 2).

The MCA, with $8.5 \mathrm{~cm}$ in length and $0.4 \mathrm{~cm}$ in diameter, ran horizontally to the left in the transverse mesocolon and bifurcated into right and left branch. The right branch formed one arcade which almost went through all of the tranverse colon. The left branch ran to the splenic flexure and communicated with the ascending branch of the left colic artery (LCA) (Fig. 3).

Furthermore, we observed a communicating vessel of $7 \mathrm{~cm}$ in length and $0.3 \mathrm{~cm}$ in diameter between the

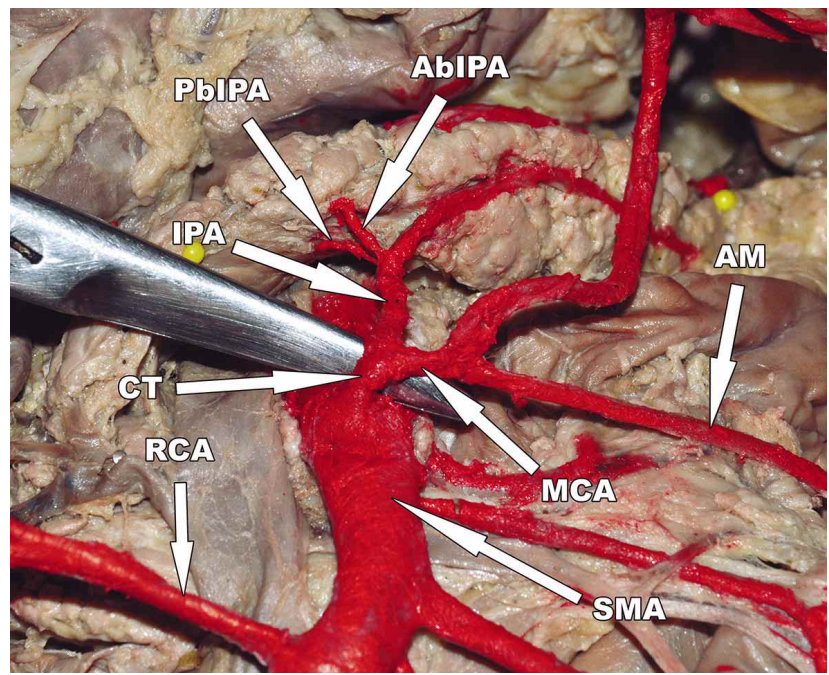

Fig. 1. Common trunk (CT) between inferior pancreatic artery (IPA) and middle colic artery (MCA), arising from superior mesenteric artery (SMA). In evidence posterior branch of inferior pancreatic artery (PbIPA) and anterior branch of inferior pancreatic artery (AbIPA). Artery of Moskowitz (AM) and right colic artery (RCA).

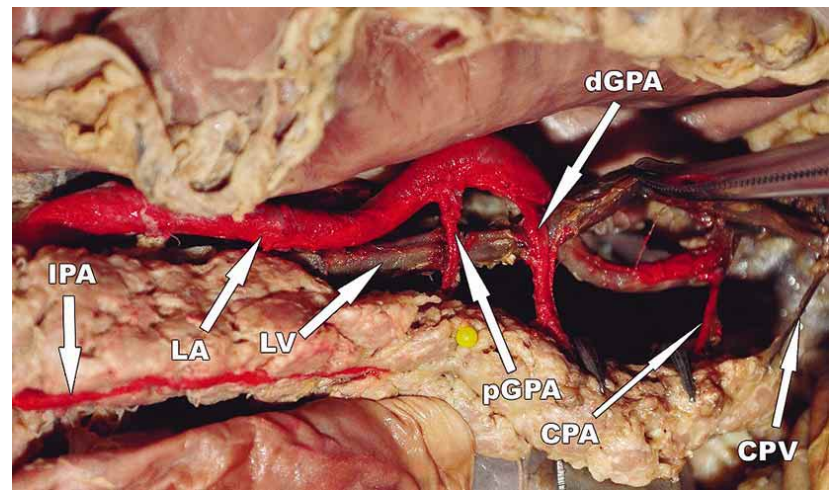

Fig. 2. Lienal artery (LA) in evidence with absence of the dorsal pancreatic artery and presence of two greater pancreatic arteries proximal (pGPA) and distal (dGPA) - and caudal pancreatic artery (CPA). Inferior pancreatic artery (IPA), lienal vein (LV) and caudal pancreatic vein (CPV). proximal portion of the MCA and the ascending branch of the LCA, also named meandering mesenteric artery or artery of Moskowitz (AM) (Fig. 3).

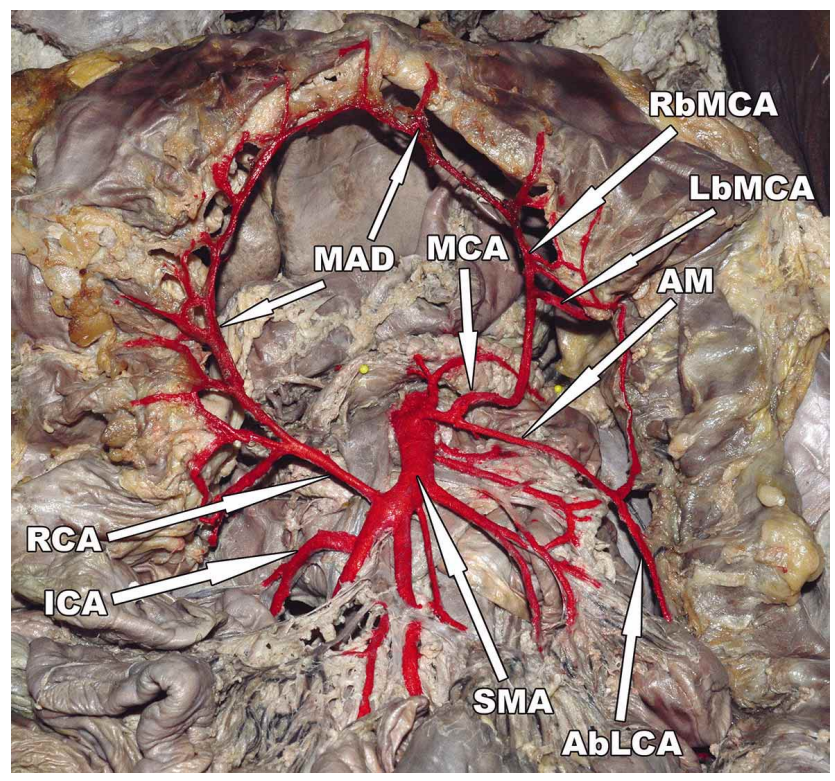

Fig. 3. Mesenteric superior artery (MSA) and its branches. Artery of Moskowitz between the proximal portion of the middle colic artery (MCA) and the ascending branch of the left colic artery (AbLCA). Marginal artery of Drummond (MAD), right branch of middle colic artery (RbMCA), left branch of middle colic artery (LbMCA), ileocolic artery (ICA).

\section{DISCUSSION}

Because pancreatic and intestinal arterial supply is extremely variable, there are continuing studies trying to show a vascular pattern in these organs (Bertelli et al.; Gardner et al.; Geboes et al.; Shatari et al.).

The pancreas is supplied by branches from the celiac trunk and from the SMA, so that each part of the gland has specific arterial branches. The head of pancreas is supplied by the pancreaticoduodenal arcade formed by the anterior and posterior superior pancreaticoduodenal arteries - usually arising as a common branch from the gastroduodenal artery - as well as by the anterior and posterior inferior pancreaticoduodenal arteries - branches of the SMA and may also arise as a common trunk. The pancreatic neck is supplied by the DPA, usually the first branch of the LA. The body and the tail of the pancreas are, respectively, supplied by the greater pancreatic artery and the CPA, both from the LA. The body of the pancreas is also supplied by the IPA, a branch of the SMA, which penetrates the inferior portion of the gland and establishes intraparenchymatous anastomosis to 
maintain adequate blood supply to the pancreas (Bertelli et al.; Gardner et al.).

The colons also show an arterial pattern of branches arising from the SMA and IMA, which reflects the embryological origin of the large intestine. The right part is supplied by the SMA through ileocolic, right colic and middle colic branches. The left colon, in turn, is supplied by the IMA, which originates about $3-4 \mathrm{~cm}$ above the aortic bifurcation (third lumbar vertebra), through the LCA, sigmoid arteries and superior rectal artery. These main branches bifurcate to form a peripheral arterial network that reaches the wall of the colon through the mesocolic border, forming the marginal artery of Drummond (Geboes et al.; Shatari et al.).

Besides the marginal artery of Drummond, there may also be central communications between the SMA and IMA. Among the variations described, the Riolan's arcade anastomotic communication between the MCA and the LCA - and the AM - communication between the proximal portion of the MCA and the ascending branch of the LCA - are emphasized (Gourley \& Gering, 2005; Kimura \& Nagai, 1995).

The variation we describe is unusual, once the IPA and the MCA arise from a common trunk of the SMA. Associated with that, the pancreatic neck was not supplied by the DPA, as classically observed, but by two small branches arising from the IPA.

In some cases of pancreatic cancer with early diagnosis, physicians may opt for conservative surgical resection with preservation of the tail and head of the pancreas depending on the location of the neoplasia. In these cases, knowledge of pancreatic vascular pattern is vital, as a mistaken ligature of one of these branches may mean loss of the preserved pancreatic portion (Loos et al., 2008; Feldman et al., 2010). The same occurs in surgical treatment of acute necrohemorrhagic pancreatitis, in which the mistaken ligature of a vessel may allow for maintenance of the hemorrhagic profile, or for necrosis of a non-affected part of the gland (Bertelli et al.; Corman et al., 2013).

Invasive colon tumors are treated surgically with broad resection of the colon, ligature of the arterial branches in their origin and resection of the mesocolon for lymphatic drainage. The surgery to be realized for treatment of transverse colon depends of the place of tumor, which determinates the lymphatic chain probably compromised. Therefore, to injuries in proximal transverse colon the preferential procedure is the expanded right hemicolectomy with ligature of MCA, right colic artery and ileocolic artery.
The tumors placed on middle third of transverse colon, close to the MCA, can be resected by transversectomy, performing only ligature of the middle colic vessels and the tranverse mesocolon. The injuries located in distal transverse colon must be resected by expanded left hemicolectomy with ligature of IMA and the left branch of MCA (Corman et al.; Shatari et al.). In the present case study, because the MCA and the IPA had a short common branch of $6 \mathrm{~mm}$, the resection can be performed after the bifurcation of this vessel, preserving the IPA.

Moskowitz et al. in 1964, described a vessel connecting the proximal portion of the MCA and the ascending branch of the LCA (Santhanam, 1995). Under good conditions of intestinal perfusion, the blood flow through this artery has little importance. However, depending on the degree of obstruction of the SMA and IMA, the AM becomes an important duct of collateral circulation and it ensures adequate blood supply to the obstructed distal segment. The greater blood flow through this artery make it dilated and tortuous, whence the name "meandering mesenteric artery". The AM is not usually observed in arteriography of the abdomen, so observation of this artery in angiographic examinations is indicative of severe stenosis of the mesenteric arteries or of its main branches (Gourley \& Gering; Kimura \& Nagai).

In this reported case, the AM was rectilinear and had a homogeneous diameter, since the mesenteric arteries and their colic branches were permeable and the colon had no signs of ischemia.

\section{CONCLUSION}

Although there is an anatomical pattern of blood supply in several organs and tissues, anatomical changes are commonly found and knowledge of them is very important in medical practice. Therefore, we emphasize that the anatomical changes described in this study have surgical and radiological significance not only to the previously discussed facts, but also to interventional abdominal emergency cases.

SILVA JÚNIOR, L. M.; ALEXANDRE, M.; GONÇALVES, L.; SILVA, F. S. \& CAETANO, A. G. Variaciones en el suministro vascular del páncreas y colon transverso: reporte de un caso. Int. J. Morphol., 32(1):190-193, 2014.

RESUMEN: Durante la disección anatómica de la cavidad abdominal del cadáver de un hombre adulto, se observó un 
patrón cambiante en el suministro vascular del páncreas y del colon transverso. La arteria pancreática inferior y la arteria cólica media surgían de un tronco común desde la arteria mesentérica superior. Además, la arteria esplénica no daba origen a la rama dorsal hasta el cuello del páncreas, más bien contaba con dos arterias pancreáticas mayores (una proximal y una distal) hasta la glándula, y una arteria caudal. También se observó una conexión entre la parte proximal de la arteria cólica media y el ramo ascendente de la arteria cólica izquierda lo que fue previamente definido como la arteria de «Moskowitz». Las implicaciones quirúrgicas de estas variaciones fueron destacadas en base a estos datos.

PALABRAS CLAVE: Variación anatómica; Flujo sanguíneo; Páncreas; Intestino grueso.

\section{REFERENCES}

Bertelli, E.; Di Gregorio, F.; Bertelli, L.; Mosca, S. The arterial blood supply of the pancreas: a review. I. The superior pancreaticoduodenal and the anterior superior pancreaticoduodenal arteries. An anatomical and radiological study. Surg. Radiol. Anat., 17(2):97-106, 13, 1995 .

Corman, M. L.; Nicholls, R. J.; Fazio, V. W. \& Bergamaschi, R. Carcinoma of the colon. In: Corman, M. L. (Ed.). Colon and Rectal Surgery. 6th ed. Philadelphia, Lippincott Williams and Wilkins, 2013. pp.625-709.

Feldman, M.; Friedman, L. S. \& Brandt, L. J. Sleisenger \& Fordtran's gastrointestinal and liver disease: pathophysiology, diagnosis, management. $9^{\text {th }}$ ed. Philadelphia, Saunders Elsevier, 2010.

Gardner, E.; Gray, D. J. \& O'Rahilly, R. Anatomy: a regional study of human structure. $4^{\text {th }}$ ed. Saunders, Philadelphia, 1975.

Geboes, K.; Geboes, K. P. \& Maleux, G. Vascular anatomy of the gastrointestinal tract. Best Pract. Res. Clin. Gastroenterol., 15(1):1-14, 2001.

Gourley, E. J. \& Gering, S. A. The meandering mesenteric artery: a historic review and surgical implications. Dis. Colon Rectum, 48(5):996-1000, 2005.

Kimura, W. \& Nagai, H. Study of surgical anatomy for duodenum-preserving resection of the head of the pancreas. Ann. Surg., 221(4):359-63, 1995.

Loos, M.; Kleeff, J.; Friess, H. \& Büchler, M. W. Surgical treatment of Pancreatic Cancer. Ann. N. Y. Acad. Sci., 1138:169-80, 2008.

Santhanam, A. The meandering mesenteric artery. Dis. Colon Rectum, 49(2):285-6, 1995.

Shatari, T.; Fujita, M.; Nozawa, K.; Haku, K.; Niimi, M.; Ikeda, Y.; Kann, S. \& Kodaira, S. Vascular anatomy for right colon lymphadenectomy. Surg. Radiol. Anat., 25(2):86-8, 2003.

\author{
Correspondence to: \\ Caetano, A. G. \\ Institute of Biological and Natural Sciences \\ Division of Human Anatomy \\ Triangulo Mineiro Federal University \\ Uberaba \\ BRAZIL \\ Email: Caetano-ag@uol.com.br
}

Received: 20-06-2013

Accepted: 02-12-2013 